\title{
Spermidine-induced improvement of reconsolidation of memory involves calcium-dependent protein kinase in rats
}

\author{
Bruna Amanda Girardi, ${ }^{1}$ Daniela Aymone Ribeiro, ${ }^{2}$ Cristiane Signor, ${ }^{2}$ Michele Muller, ${ }^{3}$ \\ Mayara Ana Gais, ${ }^{3}$ Carlos Fernando Mello, ${ }^{1}$ and Maribel Antonello Rubin ${ }^{1,2}$ \\ ${ }^{1}$ Graduate Program in Pharmacology, Center of Health Sciences, Federal University of Santa Maria, Santa Maria, RS 97105-900, \\ Brazil; ${ }^{2}$ Graduate Program in Biological Sciences: Toxicological Biochemistry, Center of Exact and Natural Sciences, \\ Federal University of Santa Maria, Santa Maria, RS 97105-900, Brazil; ${ }^{3}$ Undergraduate in Pharmacy, Center of Health \\ Sciences, Federal University of Santa Maria, Santa Maria, RS 97105-900, Brazil
}

\begin{abstract}
In this study, we determined whether the calcium-dependent protein kinase (PKC) signaling pathway is involved in the improvement of fear memory reconsolidation induced by the intrahippocampal administration of spermidine in rats. Male Wistar rats were trained in a fear conditioning apparatus using a 0.4-mA footshock as an unconditioned stimulus. Twenty-four hours after training, animals were re-exposed to the apparatus in the absence of shock (reactivation session). Immediately after the reactivation session, spermidine (2-200 pmol/site), the PKC inhibitor 3-[1-(dimethylaminopropyl)indol-3-yl]-4-(indol-3-yl) maleimide hydrochloride (GF 109203X, 0.3-30 pg/site), the antagonist of the polyamine-binding site at the NMDA receptor, arcaine $(0.2-200 \mathrm{pmol} / \mathrm{site})$, or the PKC activator phorbol 12-myristate 13acetate (PMA, $0.02-2 \mathrm{nmol} /$ site) was injected. While the post-reactivation administration of spermidine (20 and 200 $\mathrm{pmol} / \mathrm{site}$ ) and PMA (2 nmol/site) improved memory reconsolidation, GF 109203X (1, 10, and $30 \mathrm{pg} / \mathrm{site}$ ) and arcaine (200 pmol/site) impaired it. GF $109203 \mathrm{X}(0.3 \mathrm{pg} /$ site) impaired memory reconsolidation in the presence of spermidine (200 pmol/site). PMA ( $0.2 \mathrm{nmol} / \mathrm{site})$ prevented the arcaine ( $200 \mathrm{pmol} /$ site)-induced impairment of memory reconsolidation. Anisomycin $(2 \mu \mathrm{g} / \mathrm{site})$ also impaired memory reconsolidation in the presence of spermidine $(200 \mathrm{pmol} / \mathrm{site})$. Drugs had no effect when they were administered in the absence of reactivation. These results suggest that the spermidine-induced enhancement of memory reconsolidation involves PKC activation.
\end{abstract}

[Supplemental material is available for this article.]

In 1968, Schneider and Sherman showed that an immediate electroconvulsive shock ( $0.5 \mathrm{sec}$ after a reactivating footshock) impairs the recovery of a reactivated memory (Schneider and Sherman 1968). In the same year, Misanin et al. (1968) suggested that consolidated memories become labile and susceptible to modulation when they are reactivated; that is, when they are evoked, they must undergo a new stabilization process to persist (Nader et al. 2000; Sara 2000; de la Fuente et al. 2011; Gräff et al. 2014). This new stabilization process has been termed "reconsolidation" (Przybyslawski et al. 1999).

$\mathrm{N}$-methyl-D-aspartate glutamatergic receptors (NMDAr), particularly those containing the GluN2B subunit, play an important role in reconsolidation (Wang et al. 2009). In fact, the antagonist of NMDA receptors that contain the GluN2B subunit, ifenprodil, prevents consolidated and stable auditory fear memories from returning to a labile state (Ben Mamou et al. 2006). Moreover, NMDA receptor antagonists, such as MK-801 and AP5, impair fear memory reconsolidation, whereas the agonist D-cycloserine enhances it in mice and rats (Ben Mamou et al. 2006; Lee et al. 2006; Flint et al. 2013; Merlo et al. 2014). It has been shown that spermidine, which is an endogenous polyamine that binds to the interface between the GluN1 and GluN2B subunits of the NMDA receptor (Mony et al. 2011), improves the reconsolidation of the fear conditioning memory (Ribeiro et al.

\section{Corresponding author: maribel.rubin@gmail.com}

Article is online at http://www.learnmem.org/cgi/doi/10.1101/lm.039396.115.
2013). Accordingly, the antagonist of this polyamine-binding site at the NMDAr, arcaine, impairs reconsolidation, which suggests a putative physiological role for polyamines in this process (Ribeiro et al. 2013).

Current behavioral and neurochemical evidence suggests that the facilitatory effect of spermidine on memory depends on nitric oxide synthase (NOS) activity because the administration of N(G)-nitro L-arginine methyl ester (L-NAME), which is a nonspecific inhibitor of NOS, prevents the facilitatory effects of spermidine on the inhibitory avoidance task (Guerra et al. 2006). In addition, Guerra et al. (2011, 2012) showed that protein kinase A (PKA) and PKC inhibitors prevent the facilitatory effect of spermidine on the memory of an inhibitory avoidance task. Accordingly, they also prevented the spermidine-induced phosphorylation of PKC, PKA, and CREB in the hippocampus (Guerra et al. 2011,2012 ). Therefore, the effect of spermidine on memory consolidation seems to involve a sequence of biochemical events that are triggered by NMDA receptors, followed by the activation of NOS and the sequential activation of PKC and PKA/CREB signaling in the hippocampus of rats. However, no study has addressed

(C) 2015 Girardi et al. This article is distributed exclusively by Cold Spring Harbor Laboratory Press for the first 12 months after the full-issue publication date (see http://learnmem.cshlp.org/site/misc/terms.xhtml). After 12 months, it is available under a Creative Commons License (AttributionNonCommercial 4.0 International), as described at http://creativecommons. org/licenses/by-nc/4.0/. 
the neurochemical mechanisms that are involved in the improvement of memory reconsolidation by polyamines.

Reconsolidation requires dynamic changes in the activity of intracellular signaling molecules that are thought to be upstream of gene transcription, such as PKA and ERK-MAPK (Duvarci et al. 2005; Tronson et al. 2006), and of transcription factors, such as phosphoCREB (Kida et al. 2002; Milekic et al. 2007; Arguello et al. 2013). Bonini et al. (2007) showed that the post-retrieval administration of a PKC inhibitor in the CA1 region disrupts spatial memory reconsolidation, which indicates that the activation of hippocampal PKC is necessary for the reconsolidation of memory (Bonini et al. 2007). Considering these studies, we hypothesized that the facilitatory effects of SPD on memory reconsolidation involve PKC. Therefore, in the current study, we investigated whether the intrahippocampal infusion of SPD and arcaine alters memory reconsolidation in rats and whether protein synthesis and PKC are involved in the polyamine-induced improvement of fear memory reconsolidation.

\section{Results}

\section{Post-reactivation intrahippocampal spermidine} improves reconsolidation

Figure 1 shows the effect of the bilateral intrahippocampal injection of spermidine (2-200 pmol/site) immediately after reactivation on the reconsolidation of fear conditioning. Statistical analysis (one-way ANOVA) of freezing scores at testing revealed a significant effect of the drug $\left(F_{(3,14)}=3.78, \omega=0.56, P=0.035\right)$. Post hoc analysis (SNK) revealed that spermidine at the doses of 20 and $200 \mathrm{pmol} / \mathrm{site}$ increased freezing scores. These results suggest that the spermidine facilitates memory reconsolidation. As expected, statistical analysis (one-way ANOVA) of the freezing scores during the reactivation session revealed no difference between the groups $\left(F_{(3,14)}=0.04, P=0.98\right.$, reactivation data in a Supplemental Table S1), which indicates that the animals' behavior was similar between groups before drug administration.

\section{GF 109203X impairs memory reconsolidation and} prevents spermidine-induced improvement of memory Figure 2A shows the effect of the bilateral intrahippocampal injection of the PKC inhibitor 3-[1(dimethylaminopropyl) in- dol-3-yl]-4-(indol-3-yl) maleimide hydrochloride (GF 109203X) immediately post-reactivation at doses of $0.3,1,10$, or $30 \mathrm{pg} /$ site on the reconsolidation of fear conditioning. Statistical analysis (one-way ANOVA) of the freezing scores revealed a significant effect of drug treatment $\left(F_{(4,17)}=9.21, \omega=0.77, P=0.0004\right)$. Post hoc analysis (SNK) revealed that GF 109203X at the doses of 1,10 , and $30 \mathrm{pg} /$ site decreased freezing scores. These results suggest that the intrahippocampal administration of the selective PKC inhibitor impairs memory reconsolidation. As expected, statistical analysis (one-way ANOVA) of the reactivation session freezing scores revealed no difference among the groups $\left(F_{(4,17)}=0.22\right.$, $P=0.94$, reactivation data in a Supplemental Table S1), which indicates that the animals' behavior was similar between groups before drug administration.

Figure $2 \mathrm{~B}$ shows the effect of the bilateral intrahippocampal injection of GF $109203 \mathrm{X}$ at a noneffective dose $(0.3 \mathrm{pg} / \mathrm{site}$, immediately post-reactivation) on the spermidine-induced (200 $\mathrm{pmol} / \mathrm{site}$, 5-min post-reactivation) improvement of reconsolidation. Statistical analysis (two-way ANOVA) revealed a significant pretreatment (PBS or GF 109203X) versus treatment (PBS or spermidine) interaction $\left(F_{(1,16)}=5.45, \omega=0.38, P=0.032\right)$. Post hoc $F$ test for simple effect revealed a significant effect of pretreatment (PBS or GF 109203X) only in the presence of spermidine $\left(F_{(1,16)}=\right.$ 13.88, $\omega=0.75, P<0.001)$. While spermidine-induced increase of freezing scores in this experiment did not achieve statistical significance $\left(F_{(1,16)}=4.04, P<0.1, F\right.$ test for simple effect at PBS level of pretreatment factor), this increase in freezing scores allowed GF 109203X-induced decrease of freezing scores to occur. Therefore, one might conclude that PKC inhibition decreased freezing scores only in the presence of spermidine. Statistical analysis (two-way ANOVA) of reactivation freezing scores revealed no difference among groups in this experiment $\left(F_{(1,16)}=0.03, P=0.85\right.$, reactivation data in a Supplemental Table S1).

\section{Post-reactivation intrahippocampal administration of arcaine impairs reconsolidation of contextual fear memories}

Figure 3 shows the effect of the bilateral intrahippocampal injection of arcaine $(0.2-200 \mathrm{pmol} / \mathrm{site})$ immediately postreactivation on fear conditioning reconsolidation. Statistical analysis (one-way ANOVA) of freezing scores revealed a significant effect of drug treatment $\left(F_{(4,24)}=2.94\right.$, $\omega=0.45, P=0.041$ ). Post hoc analysis (SNK) revealed that arcaine at a dose of $200 \mathrm{pmol} /$ site decreased freezing scores. These results suggest that intrahippocampal administration of arcaine impairs memory reconsolidation. As expected, statistical analysis (one-way ANOVA) of the reactivation session freezing scores revealed no difference among groups $\left(F_{(4,24)}=0.41, \quad P=0.79, \quad\right.$ reactivation data in a Supplemental Table S1).

\section{Phorbol 12-myristate 13-acetate improves reconsolidation and prevents arcaine-induced} impairment of reconsolidation

Figure 1. Post-reactivation intrahippocampal administration of spermidine improves reconsolidation of contextual fear memories. (A) Rats received spermidine (SPD, 2-200 pmol/site, i.h.) or PBS, immediately after a reactivation session, and were tested for memory reconsolidation 1 d later. $\left.{ }^{*}\right) P<0.05$ compared with vehicle by the SNK Test. Data are the means + SEM percentage of freezing at testing session ( $n=4-5$ animals in each group). (B) Schematic representations of rat brain sections at two rostrocaudal planes ( -4.0 and -4.3 from bregma) taken from the atlas of Paxinos and Watson (1986). The dark squares showing the cannulae placements and infusion sites in the CA1 region of the dorsal hippocampus.
Figure 4A shows the effect of the bilateral intrahippocampal injection of the PKC activator phorbol 12-myristate 13acetate (PMA) immediately post-reactivation at doses of $0.02-2 \mathrm{nmol} /$ site on the reconsolidation of fear conditioning. 
A

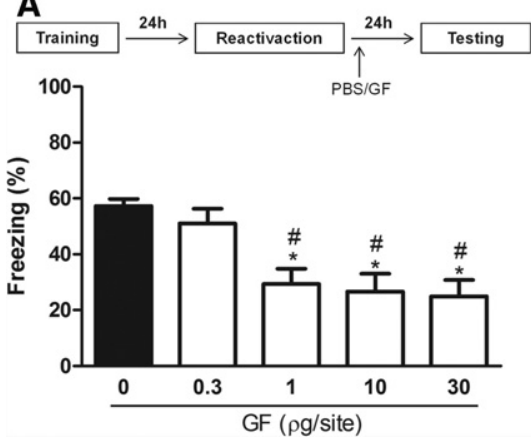

B

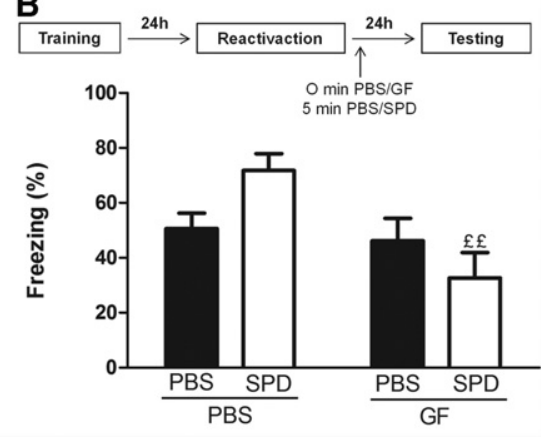

Figure 2. Post-reactivation intrahippocampal administration of GF $109203 \mathrm{X}$ impairs the reconsolidation of contextual fear memories and prevents the spermidine-induced improvement of memory reconsolidation. (A) Rats received GF $109203 X(0.3,1,10$, and $30 \mathrm{pg} / \mathrm{site}$, i.h.) or PBS, immediately after a reactivation session, and were tested for memory reconsolidation $1 \mathrm{~d}$ later. $(B)$ Rats received GF $109203 \mathrm{X}$ ( $0.3 \mathrm{pg} / \mathrm{site}$, i.h.) or PBS immediately and spermidine (SPD, $200 \mathrm{pmol} / \mathrm{site}$, i.h.) or PBS 5 min after the reactivation session, and were tested for memory reconsolidation $1 \mathrm{~d}$ later. $\left(^{*}\right) P<0.05$ compared with vehicle by the SNK. (\#) $P<0.05$ compared with GF $109203 \mathrm{X} 0.3 \mathrm{pg} / \mathrm{site}$ by the SNK. ( $£ £) ~ P<0.05$ compared with PBS/SPD group by the $F$ test for simple effect. Data are means + SEM percentage of freezing at testing session ( $n=4-8$ animals in each group).

treatment (PBS or anisomycin) versus treatment (PBS or spermidine) interaction $\left(F_{(1,16)}=29.29, \quad \omega=0.65, \quad P<\right.$ 0.001). Post hoc $F$ tests for simple effects revealed a significant effect of pretreatment (PBS or anisomycin) only in the presence of spermidine $\left(F_{(1,16)}=48.30\right.$, $\omega=0.90, P<0.0001)$ and a significant effect of treatment (PBS or spermidine) if pretreatment was PBS $\left(F_{(1,16)}=7.76, \omega=\right.$ $0.63, P<0.05)$. These results indicate that spermidine increases freezing scores per se and that it has a permissive role for the impairing effect of anisomycin. These results suggest that anisomycin impairs fear conditioning reconsolidation in the presence of spermidine. Statistical analysis (two-way ANOVA) of the reactivation freezing scores revealed no difference among groups in this experiment $\left(F_{(1,16)}=0.006, \quad P=0.93\right.$, reactivation data in a Supplemental Table S1).
Statistical analysis (one-way ANOVA) of the test freezing scores revealed a significant effect of drug $\left(F_{(3,16)}=21.63, \omega=0.86\right.$, $P=0.0001)$. Post hoc analysis (SNK) revealed that PMA $(2 \mathrm{nmol} /$ site) increased freezing scores. These results suggest that the intrahippocampal administration of PMA facilitates memory reconsolidation. As expected, statistical analysis (one-way ANOVA) of the reactivation session freezing scores revealed no difference among groups $\left(F_{(3,16)}=0.66, P=0.58\right.$, reactivation data in a Supplemental Table S1).

Figure $4 \mathrm{~B}$ shows the effect of bilateral intrahippocampal injection of PMA at a noneffective dose $(0.2 \mathrm{nmol} /$ site, immediately post-reactivation) on the impairment of reconsolidation induced by arcaine (200 pmol/site, 5-min post-reactivation). Statistical analysis (two-way ANOVA) revealed a significant pretreatment (PBS or PMA) versus treatment (PBS or arcaine) interaction $\left(F_{(1,28)}=6.11, \omega=0.41, P=0.019\right)$. Post hoc $F$ test for simple effect revealed a significant effect of treatment (PBS or arcaine) only if the animals were pretreated with $\operatorname{PBS}\left(F_{(1,28)}: 11.56, \omega=\right.$ $0.63, P<0.01)$. These results indicate that PMA prevents the arcaine-induced impairment of fear conditioning reconsolidation. Statistical analysis (two-way ANOVA) of the reactivation freezing scores also revealed no difference among groups in this experiment $\left(F_{(1,28)}=0.24, P=0.62\right.$, reactivation data in a Supplemental Table S1).

\section{Anisomycin impairs reconsolidation and prevents spermidine-induced improvement of reconsolidation}

Figure $5 \mathrm{~A}$ shows the effect of the bilateral intrahippocampal injection of anisomycin $(0.2,2,20 \mu \mathrm{g} /$ site $)$ immediately postreactivation on the reconsolidation of fear conditioning. Statistical analysis (one-way ANOVA) of the test freezing scores revealed a significant effect of $\operatorname{drug}\left(F_{(3,16)}=11.16, \omega=0.77, P=0.0003\right)$. Post hoc analysis (SNK) revealed that anisomicyn $(20 \mu \mathrm{g} / \mathrm{site})$ decreases freezing scores. These results suggest that intrahippocampal anisomycin impairs memory reconsolidation. As expected, statistical analysis (one-way ANOVA) of reactivation session freezing scores revealed no difference among groups $\left(F_{(3,16)}=\right.$ $0.33, P=0.80$, reactivation data in a Supplemental Table S1).

Figure 5B shows the effect of the bilateral intrahippocampal injection of anisomycin at a noneffective dose $(0.2 \mu \mathrm{g} / \mathrm{site}$, immediately post-reactivation) on the spermidine-induced (200 pmol/ site, 5-min post-reactivation) improvement of reconsolidation. Statistical analysis (two-way ANOVA) revealed a significant pre-
The effects of spermidine, GF 109203X, arcaine, PMA and anisomycin are specific for reconsolidation of contextual fear memories

Figure 6 shows the effect of the bilateral intrahippocampal injection of spermidine (200 pmol/site), GF 109203X (30 pg/site), arcaine (200 pmol/site), PMA ( $2 \mathrm{nmol} / \mathrm{site})$, or anisomycin $(20 \mu \mathrm{g} / \mathrm{site}) 24 \mathrm{~h}$ after training in the absence of a reactivation session on the reconsolidation of fear conditioning. Statistical analysis (one-way ANOVA) of the freezing scores revealed that spermidine, GF 109203X, arcaine, PMA, and anisomycin did not alter contextual fear conditioning in the absence of reactivation $\left(F_{(5,23)}=0.66, P=0.65\right)$.

\section{Discussion}

The main findings of the current study were that while the i.h. injection of spermidine improved memory reconsolidation, arcaine impaired it. While phorbol 12-myristate 13-acetate prevented the arcaine-induced impairment of reconsolidation, GF 109203X

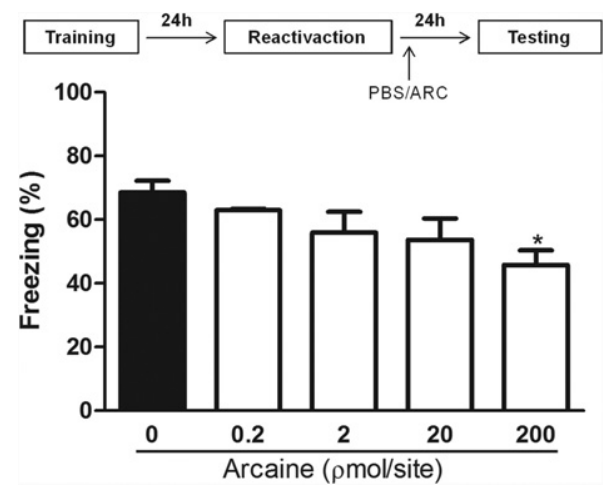

Figure 3. Post-reactivation intrahippocampal administration of arcaine impairs the reconsolidation of contextual fear memories. Rats received arcaine (ARC, $0.2-200 \mathrm{pmol} / \mathrm{site}$, i.h.) or PBS, immediately after the reactivation session, and were tested for memory reconsolidation $1 \mathrm{~d}$ later. $\left(^{*}\right)$ $P<0.05$ compared with vehicle by the SNK Test. Data are the means + SEM percentage of freezing at testing session $(n=5-6$ animals in each group). 
A

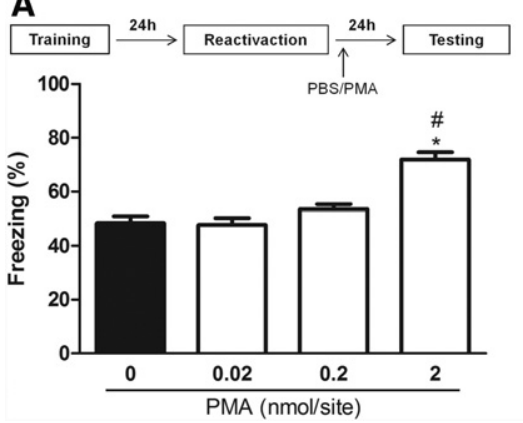

B
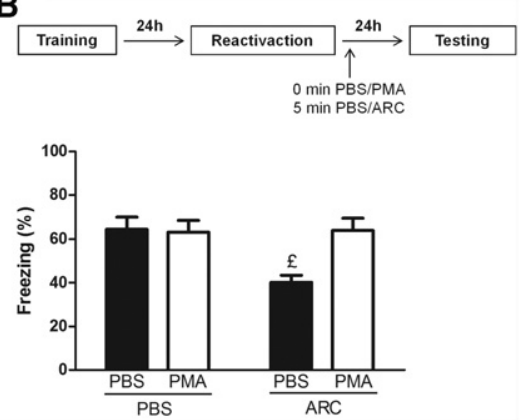

Figure 4. Post-reactivation intrahippocampal administration of phorbol 12-myristate 13-acetate (PMA) improves the reconsolidation of contextual fear memories and prevents arcaine-induced impairment of memory reconsolidation. ( $A$ ) Rats received PMA (0.02-2 nmol/site, i.h.) or PBS, immediately after a reactivation session, and were tested for memory reconsolidation $1 \mathrm{~d}$ later. $(B)$ Rats received PMA $(0.2 \mu \mathrm{g} / \mathrm{site}$, i.h.) or PBS immediately and arcaine (ARC, $200 \mathrm{pmol} / \mathrm{site}$, i.h.) or PBS $5 \mathrm{~min}$ after the reactivation session, and were tested for memory reconsolidation $1 \mathrm{~d}$ later. $\left(^{*}\right) P<0.05$ compared with vehicle by the SNK. (\#) $P<0.05$ compared with PMA $0.02-0.2 \mathrm{nmol} /$ site by the SNK. $(£) P<0.05$ compared with PBS/PBS group by the $F$ test for simple effect. Data are means + SEM percentage of freezing at testing session ( $n=5-8$ animals in each group).

decreased reconsolidation in the presence of spermidine. Finally, spermidine had a permissive role for the impairing effect of anisomycin on memory reconsolidation.

The currently reported spermidine-induced improvement of memory reconsolidation (Fig. 1A) is in agreement with Ribeiro et al. (2013), who showed that the systemic injection of spermidine facilitates the reconsolidation of fear conditioning memory (Ribeiro et al. 2013). Moreover, it implies the existence of polyaminergic modulation in the dorsal hippocampus in the reconsolidation of fear conditioning memory, a view that is fully corroborated by the finding that i.h. arcaine, a polyaminergic antagonist, disrupts memory reconsolidation (Fig. 3). Accordingly, pharmacological, functional imaging, and lesioning studies indicate an important role for the dorsal hippocampus in the reconsolidation of contextual fear conditioning (Boccia et al. 2010; Jobim et al. 2012; Lee et al. 2013; De Jaeger et al. 2014). These findings may also be interpreted as additional evidence supporting a role for hippocampal NMDA receptors, particularly those containing the GluN2 subunit, in memory reconsolidation (Pedreira et al. 2002; Lee et al. 2006; Ribeiro et al. 2013), as far as the agonist and the antagonist of the polyaminebinding site at the NMDAr improved and disrupted memory reconsolidation, respectively.

The PKC family of Ser/Thr kinases (Nishizuka 1995) regulates neuronal activity at different levels, including neurotransmitter release, neurotransmitter receptor function, and gene expression (Ben-Ari et al. 1992; Meberg et al. 1993; Macek et al. 1998; Manseau et al. 1998; Kleschevnikov and Routtenberg 2001). There are at least 10 genes coding for PKC family members. Based on their structure and sensitivity to $\mathrm{Ca}^{2+}$ and diacylglycerol (DAG), these isoforms have been classified as conventional $(\alpha, \beta$, and $\gamma)$, novel $(\delta, \varepsilon, \eta, \theta$, and $\mu)$, and atypical PKCs $(\zeta$ and $\lambda / \iota)$, which are structurally homologous, but can be regulated independently of calcium (Parekh et al. 2000; Weeber et al. 2000; Ohno and
A

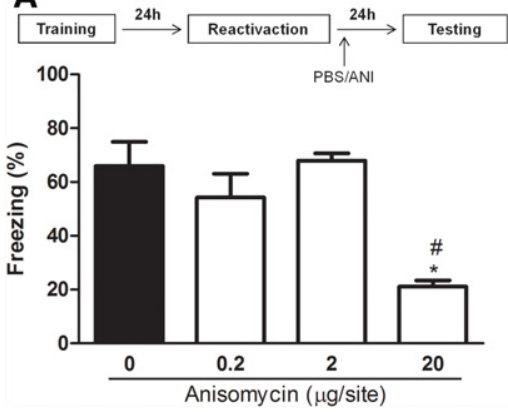

Figure 5. Post-reactivation intrahippocampal administration of anisomycin impairs the reconsolidation of contextual fear memories and prevents spermidine-induced improvement of memory reconsolidation. (A) Rats received anisomycin $(0.2-20 \mu \mathrm{g} /$ site, i.h.) or PBS, immediately after a reactivation session, and were tested for memory reconsolidation $1 \mathrm{~d}$ later. (B) Rats received anisomycin (ANI, 2 $\mu \mathrm{g} / \mathrm{site}$, i.h.) or PBS immediately and spermidine (SPD, $200 \mathrm{pmol} / \mathrm{site}$, i.h.) or PBS $5 \mathrm{~min}$ after the reactivation session, and were tested for memory reconsolidation $1 \mathrm{~d}$ later. $(*) P<0.05$ compared with vehicle by the SNK. (\#) $P<0.05$ compared with Anisomycin $0.2-2 \mu /$ site by the SNK. $(£) P<0.05$ compared with PBS/PBS group by the $F$ test for simple effect. $(£ £) P<0.05$ compared with PBS $/$ SPD group by the $F$ test for simple effect. Data are the means + SEM percentage of freezing at testing session ( $n=5$ animals in each group). 


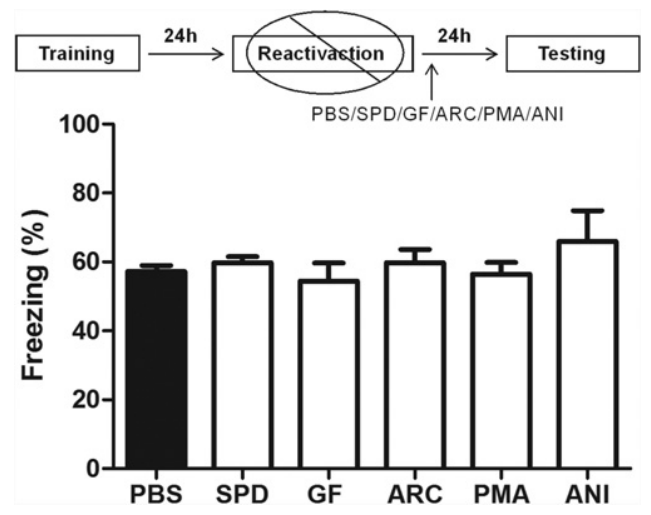

Figure 6. Spermidine, phorbol 12-myristate 13-acetate (PMA), arcaine, GF109203X, and anisomycin are specific for reconsolidation of contextual fear memories. Rats received an intrahippocampal administration of PBS, spermidine (SPD, $200 \mathrm{pmol} / \mathrm{site}), \mathrm{GF} 109203 \mathrm{X}$ (30 pg/site), arcaine (ARC, $200 \mathrm{pmol} / \mathrm{site}$ ), PMA (2 nmol/site), anisomycin (ANI, $20 \mu \mathrm{g} / \mathrm{site}) 24 \mathrm{~h}$ after training in the absence of reactivation session, and were tested for memory reconsolidation $1 \mathrm{~d}$ later. Data are means + SEM percentage of freezing in the testing session ( $n=4-5$ animals in each group).

The finding that anisomycin disrupts memory reconsolidation in the presence of spermidine suggests the involvement of protein synthesis in the currently described effects of spermidine. These results are in agreement with previous studies that showed that consolidation and reconsolidation require protein synthesis (Nader et al. 2000; Sol Fustiñana et al. 2014). Indeed, the injection of protein synthesis inhibitors before or after training or after reactivation impairs long-term memory (Nader et al. 2000; Lopez et al. 2015). Nevertheless, anisomycin can have other important effects on neurobiological function, including the induction of immediate early genes (Edwards and Mahadevan 1992; Rudy et al. 2006; Gold 2008; Radulovic and Tronson 2008), alterations in synaptic release (Canal et al. 2007), and profound suppression of neural activity (Sharma et al. 2012; Greenberg et al. 2014). Therefore, we cannot rule out that other effects of anisomycin unrelated to protein synthesis inhibition interfere in the spermidine-induced improvement of memory reconsolidation.

Hirose et al. (2015) recently showed that polyamines, particularly spermidine, can permeate NMDA receptors. Therefore, it is possible that a certain amount of extracellular spermidine may reach the intracellular milieu and modulate polyamine-sensitive mechanisms, such as protein synthesis (Nishimura et al. 2009; Igarashi and Kashiwagi 2010). In this context, it has been suggested that endogenous polyamines may facilitate the action of antibiotics that interfere with protein synthesis, such as streptomycin (Nastri et al. 1993). Accordingly, Goldemberg and Algranati (1981) showed that streptomycin inhibits protein synthesis in polyamine-supplemented cells, whereas bacteria starved for polyamines were less sensitive to the action of the antibiotic (Goldemberg and Algranati 1981). Although the structures of streptomycin and anisomycin differ markedly, polyamines may facilitate the anisomycin-induced inhibition of protein synthesis. This would explain not only why anisomycin (by inhibiting protein synthesis) decreases the facilitatory effect of spermidine on memory but also why spermidine clearly facilitates the memory impairment induced by anisomycin. However, further studies are necessary to determine whether polyamines facilitate the inhibitory effect of anisomycin on protein synthesis in brain cells.

In summary, this study showed that the intrahippocampal injection of GF 109203X impairs memory reconsolidation in the presence of spermidine and that the injection of PMA prevents the arcaine-induced impairment of memory reconsolidation.
These findings suggest that ligands of the polyamine binding site at the NMDA receptor modulate memory reconsolidation by PKC-mediated mechanisms.

\section{Materials and Methods}

\section{Animals}

Experimentally naive adult male Wistar rats (260-320 g, $n=210)$, from the animal house of the Federal University of Santa Maria were used. The animals were housed four to a cage on a 12-h day/night cycle (lights on at 7:00 a.m.) at a temperature of $21^{\circ} \mathrm{C}$ with water and standard laboratory chow (Guabi) ad libitum. All experimental procedures were conducted in accordance with the policies on the use of animals and humans in neuroscience research, revised and approved by the Society for Neuroscience Research in January 1995 and with the institutional and national regulations for animal research (process 068/2011).

\section{Surgery}

Rats were anesthetized with ketamine $(80 \mathrm{mg} / \mathrm{kg})$ and xylazine $(8$ $\mathrm{mg} / \mathrm{kg}$, i.p.) and were implanted with two 27 -gauge guide cannulae placed 1-mm above the CA1 region of the dorsal hippocampus at the following coordinates: $A=4.0 \mathrm{~mm} ; L=3.0 \mathrm{~mm}$; and $V=$ $2.0 \mathrm{~mm}$ (Paxinos and Watson 1986). Placement of injections was histologically verified, as described elsewhere (Rubin et al. 1997). A total of 222 animals were subjected to stereotaxic surgery. Twelve animals (6\%) were excluded due to incorrect cannula placement. Only data from the animals with correct cannula placement were analyzed.

\section{Drugs}

$\mathrm{N}$-(3-aminopropyl)-1.4-butanediamine trihydrochloride (spermidine; Sigma), 3-[1(dimethylaminopropyl) indol-3-yl]-4-(indol3-yl) maleimide hydrochloride (GF 109203X; Sigma), 1,4-diguanidinobutane sulfate (arcaine; Pfaltz \& Bauer), phorbol 12-myristate 13-acetate (PMA; Sigma) or anisomycin (Sigma) were used. Spermidine, arcaine, and GF 109203X were dissolved in 50-mM phosphate-buffered saline solution (PBS; pH 7.4). Anisomycin was dissolved in $1 \mathrm{M} \mathrm{HCl}$ and diluted with PBS to the concentration of $50 \mathrm{mg} / \mathrm{mL}$. The $\mathrm{pH}$ of the solution was adjusted to 7.4 with $0.15 \mathrm{M} \mathrm{NaOH}$ and the concentration adjusted to $40 \mathrm{mg} / \mathrm{mL}$ with PBS. PMA was dissolved in DMSO and diluted to the final concentration of $0.05 \%$ DMSO (v/v) with PBS. Drugs were bilaterally injected into the hippocampus (i.h., $0.5 \mu \mathrm{L} /$ brain hemisphere for 1 $\mathrm{min}$ ). The injections were performed using an infusion pump and a 30-gauge needle fitted into the guide cannula. The tip of the infusion needle protruded $1.0-\mathrm{mm}$ beyond that of the guide cannula into the CA1 region in the dorsal hippocampus. The needles were left in place for additional $60 \mathrm{sec}$ to minimize backflow. Doses were selected based on previous studies (Guerra et al. 2012) and pilot experiments.

\section{Conditioning apparatus}

Contextual fear conditioning training, reactivation, and testing took place in a fear conditioning chamber $(30 \times 25 \times 25 \mathrm{~cm})$ located in a well-lit room. The front wall and ceiling of the chamber were made of clear acrylic plastic, whereas the lateral and rear walls were made of opaque plastic. The floor of the chamber consisted of 32 stainless steel rods (3-mm diameter) spaced 1-cm apart and wired to a shock generator. The chamber was cleaned with $30 \%$ ethylic alcohol before and after each rat occupied it.

\section{Behavioral procedure}

\section{Contextual fear conditioning}

In the conditioning trial, each animal was subjected to a single fear conditioning training session, as described by Rubin et al. (2004) with some modifications. In brief, the rat was placed in 
the conditioning chamber (conditioned stimulus, CS) and habituated to the apparatus for $3 \mathrm{~min}$. Immediately after habituation, three 1-sec, 0.4-mA footshocks (unconditioned stimulus, US) were delivered. The shocks were delivered 40-sec apart. After the last US, rats were allowed to stay in the chamber for additional $60 \mathrm{sec}$ before returning to their home cages.

\section{Reactivation and testing sessions}

The animals were subjected to reactivation and testing sessions according to Ribeiro et al. (2013). Briefly, $24 \mathrm{~h}$ after conditioning, rats were re-exposed to the same conditioning context for 3 min in the absence of footshock (reactivation session). The animals were returned to their home cages immediately after the reactivation session. Twenty-four hours after reactivation, each rat was placed back in the conditioning chamber and a 6-min test was performed. During this time, no shock was given. The rat was observed every 4 sec to assess whether it was freezing by a trained observer who was unaware of the experimental treatment conditions. Data were converted to the percentage of samples scored as freezing. The percentage of samples scored as freezing over 6 min was taken as a contextual fear conditioning measure.

\section{Experimental groups}

\section{Experiment 1}

This experiment was designed to investigate the effect of the intrahippocampal administration of spermidine on memory reconsolidation. Animals were trained in the fear conditioning apparatus, as described above. Immediately after the reactivation session, the animals were injected with PBS or spermidine $(2,20$, or $200 \mathrm{pmol} / \mathrm{site}$ ), and $24 \mathrm{~h}$ later, they were tested in the fear conditioning apparatus, where their freezing responses were scored as described above.

\section{Experiment 2}

This experiment was designed to investigate the effect of intrahippocampal administration of the PKC inhibitor GF 109203X on memory reconsolidation, as well as the involvement of PKC in the effect of spermidine on memory reconsolidation. Animals were trained in the fear conditioning apparatus as described above. Immediately after the reactivation session, the animals were injected with PBS or GF $109203 X(0.3,1,10$, or $30 \mathrm{pg} / \mathrm{site})$, and $24 \mathrm{~h}$ later, they were tested in the fear conditioning apparatus, where their freezing responses were scored.

Once it was determined that GF $109203 \mathrm{X}$ at a dose of 0.3 $\mathrm{pg} /$ site did not alter memory reconsolidation, the effect of GF 109203X on the spermidine-induced improvement of memory reconsolidation was determined. The animals were trained in the fear conditioning apparatus, as described above. Immediately after the reactivation session, they were injected with PBS or GF 109203X (0.3 pg/site), and 5 min later, they were injected with PBS or spermidine (200 pmol/site). This dose of spermidine (200 $\mathrm{pmol} /$ site) was selected because it improved memory reconsolidation, as shown in Figure 1. Twenty-four hours after reactivation, the animals were tested in the fear conditioning apparatus and their freezing responses were scored.

\section{Experiment 3}

This experiment was designed to investigate the effect of the intrahippocampal administration of arcaine on memory reconsolidation. Animals were trained in the fear conditioning apparatus as described above. Immediately after the reactivation session, the animals were injected (i.h.) with PBS or arcaine $(0.2,2,20$, or $200 \mathrm{pmol} / \mathrm{site})$, and $24 \mathrm{~h}$ later, they were tested in the fear conditioning apparatus where their freezing responses were scored.

\section{Experiment 4}

This experiment was designed to investigate the effect of PMA, a PKC activator, on memory reconsolidation to determine whether PMA prevents the arcaine-induced impairment of memory reconsolidation. Animals were trained in the fear conditioning apparatus as described above. Immediately after the reactivation session, the animals were injected (i.h.) with PBS or PMA (0.02, 0.2 or 2 $\mathrm{nmol} / \mathrm{site})$, and $24 \mathrm{~h}$ later, they were tested in the fear conditioning apparatus where their freezing responses were scored as described above.

Once it was determined that PMA at a dose of $0.2 \mathrm{nmol} / \mathrm{site}$ did not alter the reconsolidation of memory, the effect of PMA on the arcaine-induced impairment of memory reconsolidation was determined. The animals were trained in the fear conditioning apparatus as described above. Immediately after the reactivation session, the animals were injected with PBS or PMA (0.2 nmol/site), and $5 \mathrm{~min}$ later, they were injected with PBS or arcaine $(200 \mathrm{pmol} /$ site). Twenty-four hours after reactivation, the animals were tested in the fear conditioning apparatus and their freezing responses were scored.

\section{Experiment 5}

This experiment was designed to investigate the involvement of protein synthesis in the effect of spermidine on memory reconsolidation.

Animals were trained in the fear conditioning apparatus as described above. Immediately after the reactivation session, the animals were injected (i.h.) with PBS or a protein synthesis inhibitor, anisomycin $(0.2,2$, or $20 \mu \mathrm{g} / \mathrm{site})$, and $24 \mathrm{~h}$ later, they were tested in the fear conditioning apparatus where their freezing responses were scored as described above.

Once it was determined that anisomycin at a dose of $0.2 \mu \mathrm{g} /$ site did not alter memory reconsolidation, the effect of anisomycin on the spermidine-induced improvement of memory reconsolidation was determined. The animals were trained in the fear conditioning apparatus as described above. Immediately after the reactivation session, the animals were injected with PBS or anisomycin $(0.2 \mu \mathrm{g} / \mathrm{site}, \mathrm{i} . \mathrm{h}$.$) , and 5 \mathrm{~min}$ later, they were injected with PBS or SPD (200 pmol/site, i.h.). Twenty-four hours after reactivation, the animals were tested in the fear conditioning apparatus and their freezing responses were scored.

\section{Experiment 6}

Control experiments without the memory reactivation session were performed to evaluate whether the effects of spermidine, GF 109203X, arcaine, PMA, or anisomycin are specific for the reconsolidation of contextual fear memories. Animals were trained in the fear conditioning apparatus but without the memory reactivation session $24 \mathrm{~h}$ later. The animals were injected (i.h.) with PBS, spermidine (200 pmol/site), GF 109203X (30 pg/ site), arcaine (200 pmol/site), PMA ( $2 \mathrm{nmol} /$ site) or anisomycin $(20 \mu \mathrm{g} / \mathrm{site}) 24 \mathrm{~h}$ after training, and $24 \mathrm{~h}$ later, they were tested in the fear conditioning apparatus and had their freezing responses scored.

\section{Statistics}

The data were analyzed by one or two-way analysis of variance (ANOVA), depending on the experimental design. Post hoc analyses were carried out by the Student-Newman-Keuls test and $F$ test for simple effect when indicated. $P<0.05$ was considered significant.

\section{Acknowledgments}

This study was supported by Conselho Nacional de Desenvolvimento Científico e Tecnológico-CNPq (306468/2014-0) and Fundação de Amparo à Pesquisa do Rio Grande do Sul-FAPERGS. C.F.M. and M.A.R. are recipients of CNPq productivity fellowships. B.A.G. and C.S. are recipients of Coordenação de 
Aperfeiçoamento de Pessoal de Nível Superior-CAPES fellowships. M.A.G. is a recipient of a FAPERGS fellowship.

\section{References}

Arguello AA, Ye X, Bozdagi O, Pollonini G, Tronel S, Bambah-Mukku D, Huntley GW, Platano D, Alberini CM. 2013. CCAAT enhancer binding protein $\delta$ plays an essential role in memory consolidation and reconsolidation. J Neurosci 33: 3646-3658.

Ben-Ari Y, Aniksztejn L, Bregestovski P. 1992. Protein kinase C modulation of NMDA currents: an important link for LTP induction. Trends Neurosci 15: $333-339$

Ben Mamou C, Gamache K, Nader K. 2006. NMDA receptors are critical for unleashing consolidated auditory fear memories. Nat Neurosci 9: 1237-1239.

Boccia MM, Blake MG, Krawczyk MC, Baratti CM. 2010. Hippocampal alpha7 nicotinic receptors modulate memory reconsolidation of an inhibitory avoidance task in mice. Neuroscience 171: 531-543.

Bonini JS, Da Silva WC, Bevilaqua LR, Medina JH, Izquierdo I, Cammarota M. 2007. On the participation of hippocampal PKC in acquisition, consolidation and reconsolidation of spatial memory. Neuroscience 147: 37-45.

Canal CE, Chang Q, Gold PE. 2007. Amnesia produced by altered release of neurotransmitters after intraamygdala injections of a protein synthesis inhibitor. Proc Natl Acad Sci 104: 12500-12505.

Crespo JA, Stöckl P, Ueberall F, Jenny M, Saria A, Zernig G. 2012. Activation of PKC $\zeta$ and PKM $\zeta$ in the nucleus accumbens core is necessary for the retrieval, consolidation and reconsolidation of drug memory. PLoS One 7: e30502.

De Jaeger X, Courtey J, Brus M, Artinian J, Villain H, Bacquié E, Roullet P. 2014. Characterization of spatial memory reconsolidation. Learn Mem 21: $316-324$

De la Fuente V, Freudenthal R, Romano A. 2011. Reconsolidation or extinction: transcription factor switch in the determination of memory course after retrieval. J Neurosci 31: 5562-5573.

Duvarci S, Nader K, LeDoux JE. 2005. Activation of extracellular signal-regulated kinase- mitogen-activated protein kinase cascade in the amygdala is required for memory reconsolidation of auditory fear conditioning. Eur J Neurosci 21: 283-289.

Edwards DR, Mahadevan LC. 1992. Protein synthesis inhibitors differentially superinduce c-fos and c-jun by three distinct mechanisms: lack of evidence for labile repressors. EMBO J 11: 2415-2424.

Flint RW Jr, Noble LJ, Ulmen AR. 2013. NMDA receptor antagonism with MK-801 impairs consolidation and reconsolidation of passive avoidance conditioning in adolescent rats: evidence for a state dependent reconsolidation effect. Neurobiol Learn Mem 101: 114-119.

Gold PE. 2008. Protein synthesis inhibition and memory: formation vs amnesia. Neurobiol Learn Mem 89: 201-211.

Goldemberg SH, Algranati ID. 1981. Polyamine requirement for streptomycin action on protein synthesis in bacteria. Eur J Biochem 117: $251-255$.

Gräff J, Joseph NF, Horn ME, Samiei A, Meng J, Seo J, Rei D, Bero AW, Phan TX, Wagner F, et al. 2014. Epigenetic priming of memory updating during reconsolidation to attenuate remote fear memories. Cell 156: 261-276.

Greenberg A, Ward-Flanagan R, Dickson CT, Treit D. 2014. ANI inactivation: unconditioned anxiolytic effects of anisomycin in the ventral hippocampus. Hippocampus 24: 1308-1316.

Guerra GP, Mello CF, Sauzem PD, Berlese DB, Furian AF, Tabarelli Z, Rubin MA. 2006. Nitric oxide is involved in the memory facilitation induced by spermidine in rats. Psychopharmacology (Berl) 186: $150-158$.

Guerra GP, Mello CF, Bochi GV, Pazini AM, Fachinetto R, Dutra RC, Calixto JB, Ferreira J, Rubin MA. 2011. Hippocampal PKA/CREB pathway is involved in the improvement of memory induced by spermidine in rats. Neurobiol Learn Mem 96: 324-332.

Guerra GP, Mello CF, Bochi GV, Pazini AM, Rosa MM, Ferreira J, Rubin MA. 2012. Spermidine-induced improvement of memory involves a cross-talk between protein kinases $C$ and A. J Neurochem 122: 363-373.

Hirose T, Saiki R, Yoshizawa Y, Imamura M, Higashi K, Ishii I, Toida T, Williams K, Kashiwagi K, Igarashi K. 2015. Spermidine and $\mathrm{Ca}^{2+}$, but not $\mathrm{Na}^{+}$, can permeate NMDA receptors consisting of GluN1 and GluN2A or GluN2B in the presence of $\mathrm{Mg}^{2+}$. Biochem Biophys Res Commun 463: 1190-1195.

Igarashi K, Kashiwagi K. 2010. Modulation of cellular function by polyamines. Int J Biochem Cell Biol 42: 39-51.

Jobim PF, Pedroso TR, Christoff RR, Werenicz A, Maurmann N, Reolon GK, Roesler R. 2012. Inhibition of mTOR by rapamycin in the amygdala or hippocampus impairs formation and reconsolidation of inhibitory avoidance memory. Neurobiol Learn Mem 97: 105-112.

Kida S, Josselyn SA, Peña de Ortiz S, Kogan JH, Chevere I, Masushige S, Silva AJ. 2002. CREB required for the stability of new and reactivated fear memories. Nat Neurosci 5: 348-355.

Kishimoto A, Kajikawa N, Shiota M, Nishizuka Y. 1983. Proteolytic activation of calcium-activated, phospholipid-dependent protein kinase by calcium-dependent neutral protease. J Biol Chem 258: 1156-1164.

Kleschevnikov AM, Routtenberg A. 2001. PKC activation rescues LTP from NMDA receptor blockade. Hippocampus 175: 168-175.

Lee JL, Milton AL, Everitt BJ. 2006. Reconsolidation and extinction of conditioned fear: inhibition and potentiation. J Neurosci 26: 10051-10056.

Lee AM, Kanter BR, Wang D, Lim JP, Zou ME, Qiu C, McMahon T, Dadgar J, Fischbach-Weiss SC, Messing RO. 2013. Prkcz null mice show normal learning and memory. Nature 493: 416-419.

Lopez J, Gamache K, Schneider R, Nader K. 2015. Memory retrieval requires ongoing protein synthesis and NMDA receptor activity-mediated AMPA receptor trafficking. I Neurosci 35: 2465-2475.

Macek TA, Schaffhauser H, Conn PJ. 1998. Protein kinase C and A3 adenosine receptor activation inhibit presynaptic metabotropic glutamate receptor (mGluR) function and uncouple mGluRs from GTP-binding proteins. J Neurosci 18: 6138-6146.

Manseau F, Sossin WS, Castellucci VF. 1998. Long-term changes in excitability induced by protein kinase $\mathrm{C}$ activation in Aplysia sensory neurons. J Neurophysiol 79: 1210-1218.

Meberg PJ, Barnes CA, McNaughton BL, Routtenberg A. 1993. Protein kinase $\mathrm{C}$ and F1/GAP-43 gene expression in hippocampus inversely related to synaptic enhancement lasting 3 days. Proc Natl Acad Sci 90: $12050-12054$

Merlo E, Milton AL, Goozee ZY, Theobald DE, Everitt BJ. 2014. Reconsolidation and extinction are dissociable and mutually exclusive processes: behavioral and molecular evidence. J Neurosci 34: $2422-2431$.

Milekic MH, Pollonini G, Alberini CM. 2007. Temporal requirement of $\mathrm{C} / \mathrm{EBP} \beta$ in the amygdala following reactivation but not acquisition of inhibitory avoidance. Learn Mem 14: 504-511.

Misanin JR, Miller RR, Lewis DJ. 1968. Retrograde amnesia produced by electroconvulsive shock after reactivation of a consolidated memory trace. Science 160: $554-555$.

Mony L, Zhu S, Carvalho S, Paoletti P. 2011. Molecular basis of positive allosteric modulation of GluN2B NMDA receptors by polyamines. EMBO J 30: 3134-3146.

Nader K, Schafe GE, Le Doux JE. 2000. Fear memories require protein synthesis in the amygdala for reconsolidation after retrieval. Nat Neurosci, 406: 722-726.

Nastri HG, Fastame IG, Algranati ID. 1993. Polyamines modulate streptomycin-induced mistranslation in Escherichia coli. Biochim Biophys Acta 1216: 455-459.

Nishimura K, Okudaira H, Ochiai E, Higashi K, Kaneko M, Ishii I, Nishimura T, Dohmae N, Kashiwagi K, Igarashi K. 2009. Identification of proteins whose synthesis is preferentially enhanced by polyamines at the level of translation in mammalian cells. Int J Biochem Cell Biol 41: $2251-2261$.

Nishizuka Y. 1995. Protein kinase C and lipid signaling for sustained cellular responses. FASEB J 9: 484-496.

Ohno S, Nishizuka Y. 2002. Protein kinase C isotypes and their specific functions: prologue. J Biochem 132: 509-511.

Paxinos G, Watson C. 1986. The rat brain in stereotaxic coordinates, 2nd ed. Academic Press Inc., San Diego, CA.

Pedreira ME, Pérez-Cuesta LM, Maldonado H. 2002. Reactivation and reconsolidation of long-term memory in the crab Chasmagnathus: protein synthesis requirement and mediation by NMDA-type glutamatergic receptors. J Neurosci 22: 8305-8311.

Parekh DB, Ziegler W, Parker PJ. 2000. Multiple pathways control protein kinase C phosphorylation. EMBO J 19: 496-503.

Przybyslawski J, Roullet P, Sara SJ. 1999. Attenuation of emotional and nonemotional memories after their reactivation: role of $\beta$ adrenergic receptors. I Neurosci 19: 6623-6628.

Radulovic J, Tronson NC. 2008. Protein synthesis inhibitors, gene superinduction and memory: too little or too much protein? Neurobiol Learn Mem 89: 212-218.

Ribeiro DA, Mello CF, Signor C, Rubin MA. 2013. Polyaminergic agents modulate the reconsolidation of conditioned fear. Neurobiol Learn Mem 104: $9-15$.

Rubin MA, Jurach A, Zanolla GR, Boemo RL, Souza DO, de Mello CF. 1997. Intrahippocampal GMP administration improves inhibitory avoidance performance through GABAergic and glutamatergic mechanisms in rats. NeuroReport 8: $3713-3716$.

Rubin MA, Berlese DB, Stiegemeier JA, Volkweis MA, Oliveira DM, dos Santos TLB, Fenili AC, Mello CF. 2004. Intra-amygdala administration 
of polyamines modulates fear conditioning in rats. J Neurosci 24: $2328-2334$.

Rudy JW, Biedenkapp JC, Moineau J, Bolding K. 2006. Anisomycin and the reconsolidation hypothesis. Learn Mem 13: 1-3.

Sacktor TC. 2008. PKMל, LTP maintenance, and the dynamic molecular biology of memory storage. Prog Brain Res 169: 27-40.

Sara SJ. 2000. Retrieval and reconsolidation: toward a neurobiology of remembering. Learn Mem 7: 73-84.

Schneider AM, Sherman W. 1968. Amnesia: a function of the temporal relation of footshock to electroconvulsive shock. Science 159: $219-221$.

Sharma AV, Nargang FE, Dickson CT. 2012. Neurosilence: profound suppression of neural activity following intracerebral administration of the protein synthesis inhibitor anisomycin. J Neurosci 32: 2377-2387.

Sol Fustiñana M, de la Fuente V, Federman N, Freudenthal R, Romano A. 2014. Protein degradation by ubiquitin-proteasome system in formation and labilization of contextual conditioning memory. Learn Mem 21: 478-487.

Tronson NC, Wiseman SL, Olausson P, Taylor JR. 2006. Bidirectional behavioral plasticity of memory reconsolidation depends on amygdalar protein kinase A. Nat Neurosci 9: 167-169.

Volk LJ, Bachman JL, Johnson R, Yu Y, Huganir RL. 2013. PKM- $\zeta$ is not required for hippocampal synaptic plasticity, learning and memory. Nature 493: 420-423.

Wang S-H, de Oliveira Alvares L, Nader K. 2009. Cellular and systems mechanisms of memory strength as a constraint on auditory fear reconsolidation. Nat Neurosci 12: 905-912.

Weeber EJ, Atkins CM, Selcher JC, Varga AW, Mirnikjoo B, Paylor R, Leitges M, Sweatt JD. 2000. A role for the $\beta$ isoform of protein kinase C in fear conditioning. J Neurosci 20: 5906-5914.

Received July 19, 2015; accepted in revised form October 28, 2015. 


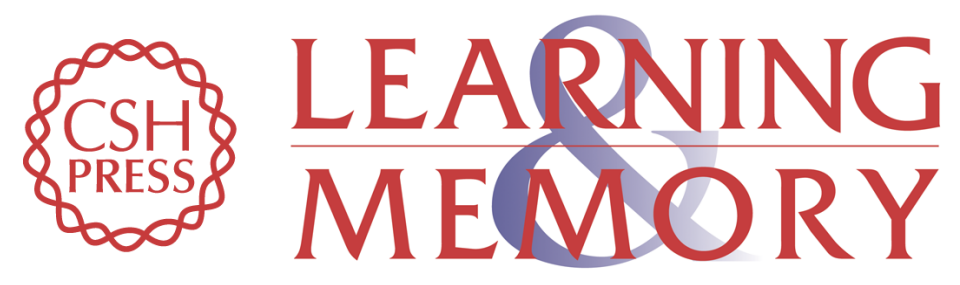

\section{Spermidine-induced improvement of reconsolidation of memory involves calcium-dependent protein kinase in rats}

Bruna Amanda Girardi, Daniela Aymone Ribeiro, Cristiane Signor, et al.

Learn. Mem. 2016, 23:

Access the most recent version at doi:10.1101/lm.039396.115

\section{Supplemental http://learnmem.cshlp.org/content/suppl/2015/12/08/23.1.21.DC1 Material}

References This article cites 57 articles, 23 of which can be accessed free at: http://learnmem.cshlp.org/content/23/1/21.full.html\#ref-list-1

Creative This article is distributed exclusively by Cold Spring Harbor Laboratory Press for the Commons first 12 months after the full-issue publication date (see

License http://learnmem.cshlp.org/site/misc/terms.xhtml). After 12 months, it is available under a Creative Commons License (Attribution-NonCommercial 4.0 International), as described at http://creativecommons.org/licenses/by-nc/4.0/.

Email Alerting Receive free email alerts when new articles cite this article - sign up in the box at the Service top right corner of the article or click here. 